\title{
Provenance study of the limestone used in the construction and restoration of the Batalha Monastery (Portugal)
}

\author{
Yufan Ding ${ }^{1}$, Jose Mirao ${ }^{1,2}$, Pedro Redol ${ }^{3}$, Luis Dias ${ }^{1}$, Patricia Moita ${ }^{1,2}$, Emma Angelini ${ }^{4}$, Sabrina \\ Grassini $^{4}$, Nicola Schiavon ${ }^{1}$ \\ ${ }^{1}$ HERCULES Laboratory, University of Évora, Largo Marquês de Marialva 8, 7000 Évora, Portugal \\ 2 Department of Geosciences, University of Évora, Rua Romão Ramalho, 7000 Évora, Portugal \\ 3 Direcao-Geral do Patrimonio Cultural, Mosteiro da Batalha, Batalha, Portugal \\ 4 Politecnico di Torino, Corso Duca degli Abruzzi 24, 10129 Torino, TO, Italy
}

ABSTRACT

To assess the provenance of the limestones used in the construction and restoration of the Batalha Monastery in central Portugal, stone samples collected from the monument and from five limestone quarries in the region surrounding the building were investigated by energy-dispersive X-ray fluorescence spectroscopy (ED-XRF), powder X-ray diffractometry (PXRD) and thermogravimetric analysis (TGA). $\mathrm{Ca}$-Sr binary diagrams from the ED-XRF result indicated the source of the samples collected from different parts of the monastery. Thinsection observation supplemented the petrographic evidence for this identification. PXRD and TGA were also used to acquire information on the mineral and chemical composition of the stones. Preliminary results suggest that the monastery baluster was made of stone from the Valinho do Rei or Reguengo do Fetal quarries, whereas part of the church railing, the north-aisle eaves arch and Royal Cloister were made with stone from the Pidiogo or Cabeço do Roxo quarries.

\section{Section: RESEARCH PAPER}

Keywords: Limestone; Batalha Monastery; archaeometry; provenance

Citation: Yufan Ding, Jose Mirao, Pedro Redol, Luis Dias, Patricia Moita, Emma Angelini, Sabrina Grassini, Nicola Schiavon, Provenance study of the limestone used in the construction and restoration of the Batalha Monastery (Portugal), Acta IMEKO, vol. 10, no. 1, article 16, March 2021, identifier: IMEKO-ACTA10 (2021)-01-16

Editor: Carlo Carobbi, University of Florence, Italy

Received May 6, 2020; In final form September 8, 2020; Published March 2021

Copyright: This is an open-access article distributed under the terms of the Creative Commons Attribution 3.0 License, which permits unrestricted use, distribution, and reproduction in any medium, provided the original author and source are credited.

Funding: This work was supported by European Union's Horizon 2020 research and innovation programme under the Marie Skłodowska-Curie grant agreement no. 766311.

Corresponding author: Yufan Ding, e-mail: yding@uevora.pt

\section{INTRODUCTION}

The Monastery of Batalha (Figure 1), known in Portugal as 'Mosteiro de Santa Maria da Vitoria', was constructed to commemorate victory over Castile, the main kingdom of present-day Spain. It is considered an architectural masterpiece, demonstrating a perfect mixture of the Gothic and Manueline styles. Initial construction began in 1386 and took two centuries to complete. In 1840, after the monastery had been nearly abandoned due to the suppression of religious orders in 1834, a first restoration programme began [1]. The Batalha Monastery has been added to the list of World Heritage sites by UNESCO. Over a century has passed since the last large-scale restoration was completed. The Batalha Monastery shows a high degree of stone decay, mainly due to bio-deterioration processes, which are

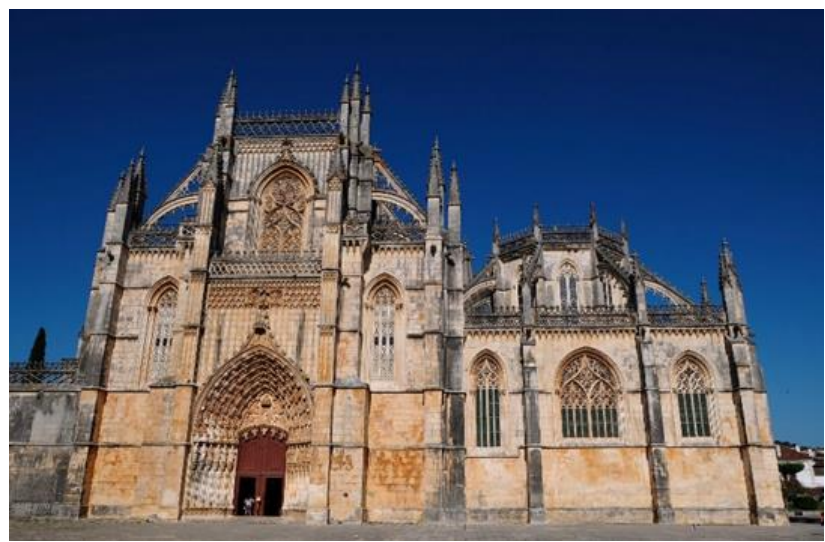

Figure 1. Monastery of Batalha 
known to play an ever-increasing role in stone decay both in urban and rural environments [2]. In order to plan an appropriate conservation strategy for the protection of the monastery, it is necessary to obtain petro-geochemical data from the stone used in its construction and successive restoration interventions [3].

There are a number of techniques that can be used for the provenance study of limestones. These include physical analytical methods, such as the uniaxial compressive strength and ultrasonic pulse velocity tests [4], optical microscopy (OM) and scanning electron microscopy (SEM) for petrographic and textural analysis [5], loss-on-ignition or thermogravimetric analysis (TGA) to measure the weight percent of $\mathrm{CaCO}_{3}$, energy dispersive $\mathrm{X}$-ray fluorescence spectroscopy (ED-XRF) to determine the chemistry, acid insoluble residue to determine the noncarbonate fraction present in the sample and X-ray diffractometry (XRD) to determine the mineralogical composition [6]. In addition, isotopic analyses and electron paramagnetic resonance can also be used to assess geochemical similarities or differences [7].

According to Aires-Barros [8], the two original limestone quarries used for the construction of Batalha Monastery in the 15th century were the Pidiogo and Valinho do Rei quarries, located $8 \mathrm{~km}$ and $7.5 \mathrm{~km}$, respectively, to the east of the monastery [7]. Soares et al. indicated that four quarries served as the main source of building stone for the restoration during the 19th century: a) the Reguengo do Fetal quarry provided the stone from 1840 to the mid-1880s; b) from 1854 until the end of the restoration activities, the Carvalhos quarry was mainly used; c) in the last decade of the 18th century, the Cabeço do Roxo and the Outeiro de Sebastião quarries were also supplying materials [10]. Despite the somewhat scarce historical documentary evidence, no detailed petrographic/geochemical study has ever been carried out to test the accuracy of the assignment of these historical quarries to the supply of the carbonate stones for the building and the restoration of the monastery. In order to contribute to this open discussion, a multi-analytical approach has been adopted for the first time in this study, combining a) a sample collection of selected stones from the monastery, b) a field survey to identify the location of and collect samples from the ancient quarries mentioned in the literature and c) petrographic and geochemical analyses using TGA, XRD, OM and SEM + ED-XRF.

\section{METHODS AND MATERIALS}

\subsection{Field investigation and sample collection}

With special permission from the Direção-Geral do Patrimonio Cultural and the Mosteiro da Batalha authorities, 12 pieces of detached stone fragments were collected for destructive or non-destructive characterisation, depending on the agreement with the monastery. The collected stone fragments came from various parts of the monastery, as labelled in Figure 2.

The location of the Pidiogo and Valinho do Rei quarries were indicated in a document released by Batalha Municipality [10]. The approximate location of Reguengo do Fetal, Cabeço do Roxo and Outeiro de Sebastião was recorded in the book ' $O$ restauro do Mosteiro da Batalha' [9], although their exact location had been lost and only rediscovered by the authors of the current study. However, despite considerable efforts, it was not possible to find one restoration quarry, Carvalhos, because it had been renamed during the last century. Field trips were made to five quarries (Figure 3), and the latitude and longitude were recorded with the help of Google Earth. Dozens of samples were

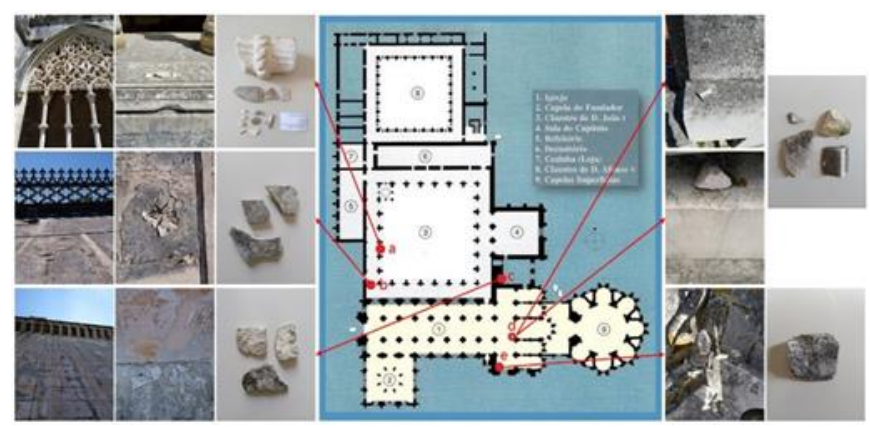

Figure 2. Locations of samples collected from Batalha Monastery: a. west gallery of the Royal Cloister, outside the 3rd window (ground-floor level); $b$. Royal cloister roof top (roof level); c. Church north-aisle eaves arch (roof level); $d$. Church roof railing (roof level); e. Church south carved baluster (roof level).

collected and marked with their corresponding origin, of which 18 samples were from Valinho do Rei and Pidiogo, believed to be the original quarries used in the construction of the monastery in the $15^{\text {th }}$ and $16^{\text {th }}$ centuries, and 16 samples were from Reguengo do Fetal, Cabeço do Roxo and Outeiro de Sebastião, used as the restoration quarries in the $19^{\text {th }}$ century.

\subsection{Thin-section petrography}

Thin sections of the stone samples were obtained using the following procedure: stones were cut into cuboids with a crosssectional area of $2 \mathrm{~cm} \times 3 \mathrm{~cm}$, and the cross-sectional surface was polished with $220 \#$ sandpaper and $400 \#$ and $1000 \#$ SiC powder, with water added sequentially. The polished stone
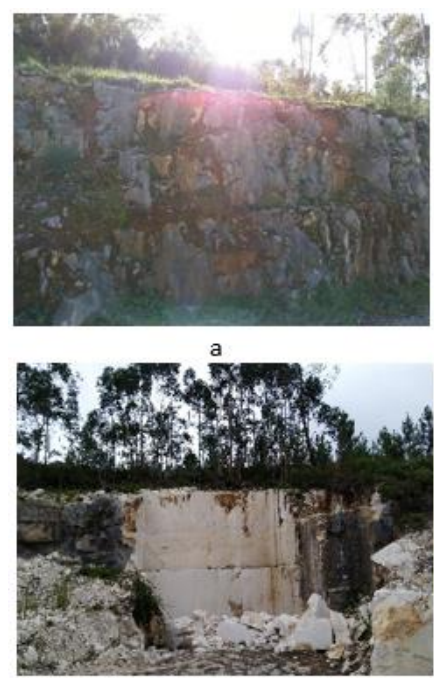

c

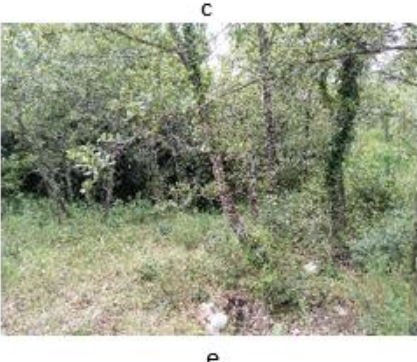

e

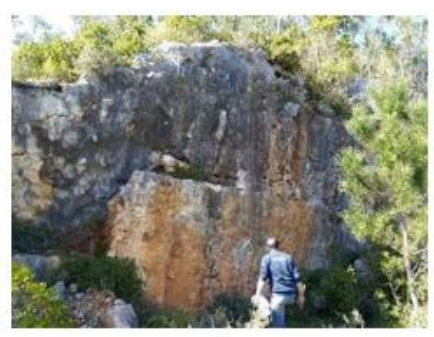

b

d

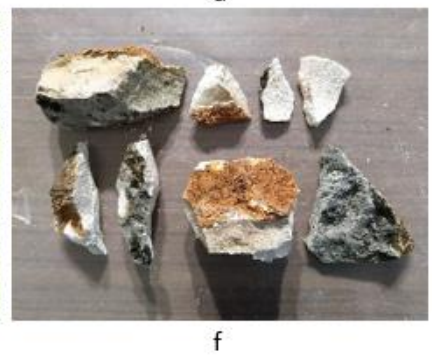

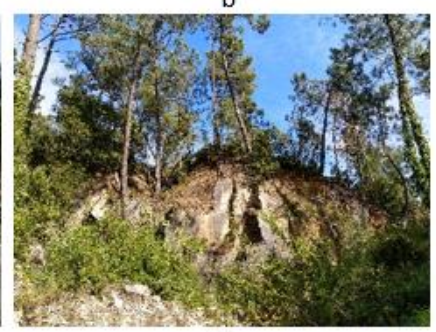

Figure 3. Photo records of field investigation to quarries: a. Pidiogo (39³9'15.7"N 844'27.9"W), b. Valinho do Rei (39³9'32.5"N 844'58.1"W), c. Reguengo do Fetal $\left(39^{\circ} 38^{\prime} 43.64^{\prime \prime} \mathrm{N} 8^{\circ} 45^{\prime} 16.19^{\prime \prime W}\right)$, d. Cabeço do Roxo $\left(39^{\circ} 35^{\prime} 39.84^{\prime \prime} \mathrm{N} 8^{\circ} 51^{\prime} 27.19^{\prime \prime} \mathrm{W}\right)$, e. Outeiro de Sebastião $\left(39^{\circ} 35^{\prime} 38.89^{\prime \prime} \mathrm{N}\right.$ $\left.8^{\circ} 51^{\prime} 27.49^{\prime \prime} \mathrm{W}\right), \mathrm{f}$. a portion of the stone samples taken from quarries. 
surface was glued to the glass slide with epoxy resin and epoxy hardener mixed at the weight ratio of 2:0.9. After the epoxy glue had set, the stones were cut and ground to a thickness of $0.1 \sim$ $0.2 \mathrm{~mm}$, and polished using 400\# and 1000\# SiC powder with water until the thickness of the stone section reached $0.025 \mathrm{~mm}$. Thin sections were observed by OM using a LEICA DM2500P.

\subsection{Powder X-ray diffraction (PXRD)}

The characterisation was carried out using a BRUKER D8 Discover X-ray diffractometer, with a CuK $\alpha$ source and operating at $40 \mathrm{kV}$ and $40 \mathrm{~mA}$. Scans were run from $3^{\circ}$ to $75^{\circ}$ $2 \theta$, with a $0.05 \circ 2 \theta$ step and a measuring time of $1 \mathrm{~s} / \mathrm{step}$ per point. The DIFFRAC.EVA software package (BRUKER/AXS $\mathrm{GmbH}$, Germany) and the PDF-2 database files (ICDD, Denver, USA) software with the PDF-2 mineralogical database were utilised to interpret the XRD patterns. The semiquantification was carried out using the reference intensity ratio method of Hubbard et al. [11]. The specimens used to conduct the characterisation were stone powders hand milled in an agate mortar.

\subsection{Thermogravimetric analysis (TGA)}

The TGA analysis was carried out using a TG-DTA NETZSCH STA 449F3 Jupiter. The temperature of the sample was increased at a heating rate of $10{ }^{\circ} \mathrm{C} / \mathrm{min}$ from $40{ }^{\circ} \mathrm{C}$ to $1,000^{\circ} \mathrm{C}$, under an $\mathrm{N}_{2}$ protective atmosphere, while the mass of the powdered sample was monitored against time and temperature. TGA applied to stone allows the quantification of minerals that are decomposed by temperature, such as minerals with structural water content or carbonates. Thermal decomposition with gaseous evolution can be detected by measuring the weight change, thus, by using stoichiometry, the content of the corresponding composition can be determined.

\subsection{X-ray fluorescence spectroscopy (XRF)}

XRF analyses were performed with a Benchtop EDXRF Bruker S2 PUMA, using a methodology similar to the one adopted by Georgiou et al. [12]. Quantifications were obtained using a regression method with 19 standard reference materials [12]. Spectra Elements 2.0 software was utilised for acquisition and data processing, reporting the final oxide/element $\left(\mathrm{Na}_{2} \mathrm{O}\right.$, $\left.\mathrm{MgO}, \mathrm{Al}_{2} \mathrm{O}_{3}, \mathrm{SiO}_{2}, \mathrm{P}_{2} \mathrm{O}_{5}, \mathrm{SO}_{3}, \mathrm{~K}_{2} \mathrm{O}, \mathrm{CaO}, \mathrm{TiO}_{2}, \mathrm{MnO}, \mathrm{FeO}\right)$ concentration and the instrumental statistical error. Two sample preparation methods were used: (1) $1.2 \mathrm{~g}$ of sample powder were fused with $12 \mathrm{~g}$ of flux (Li-tetraborate) on a Claisse LeNeo to form fused beads; (2) $10 \mathrm{~g}$ of sample powder were compressed with $1 \mathrm{~g}$ of wax (N,N'-dioctadecanoylethylenediamine) on a Specac Manual Hydraulic Press to form pellets.

\section{RESULTS AND DISCUSSION}

\subsection{Thin-section petrography}

The micrographs of the thin sections are presented in Figure 4 , in which oolites, calcite crystals and fossils may be clearly distinguished. Based on the classification scheme introduced by Flügel for identifying microfossils [14] and classifying carbonate grains in microfacies studies [15], [16], and referring to previous biostratigraphy of carbonate succession [17], [18], Table 1 summarises the petrography features of the samples.

The limestone samples from the Reguengo do Fetal and Cabeço do Roxo quarries and the limestone samples from the Batalha Monastery roof top, eaves arch and church baluster show oolites of a relatively uniform size and with compacted dispersion. However, the Valinho do Rei samples show clear differences in carbonate clasts; there are peloids with small diameters ( $0.1 \mathrm{~mm}$ on average) and ooids that are ten times larger
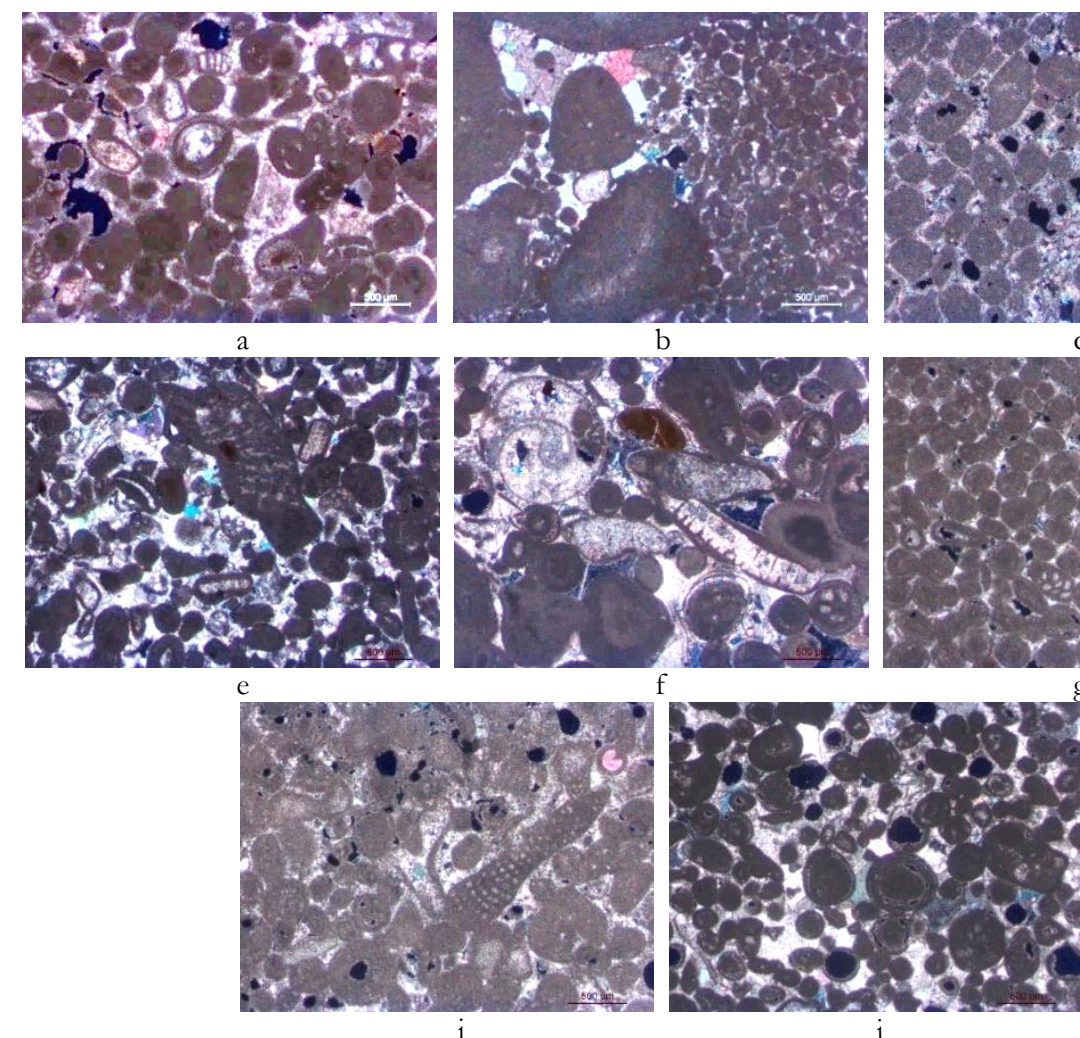

b

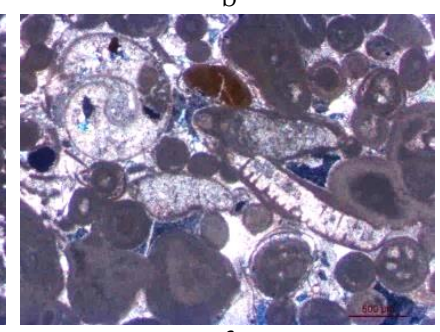

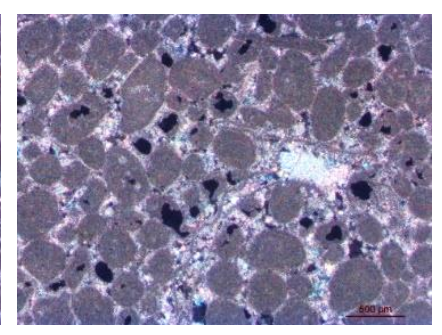

C
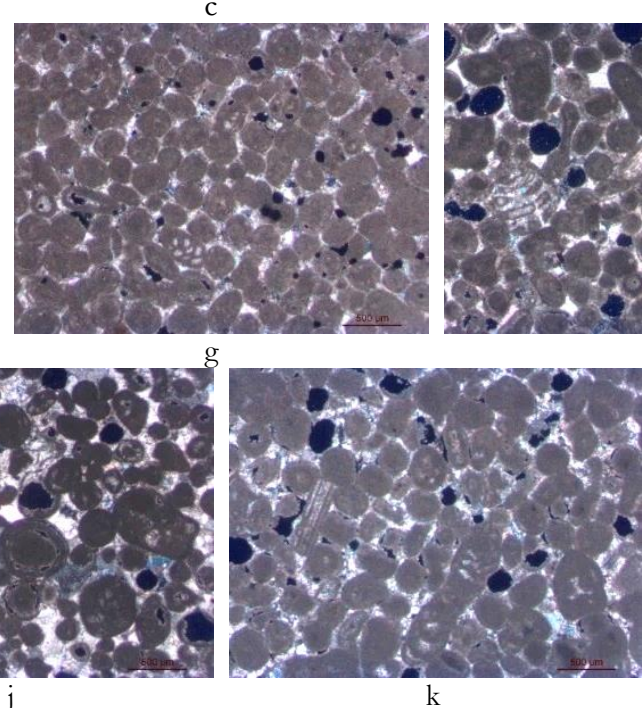
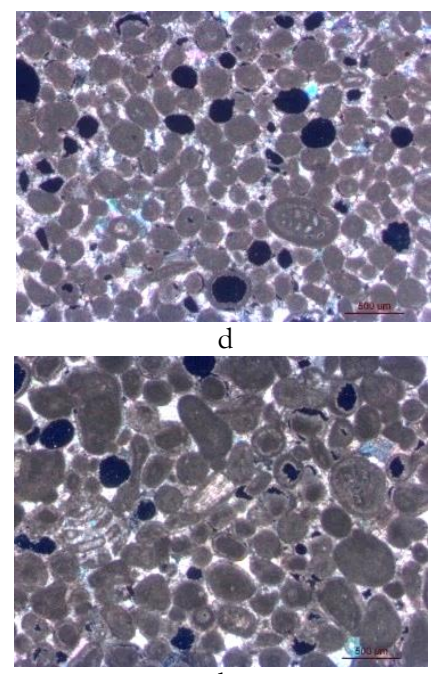

h

Figure 4. OM photos of stone samples from a. Pidogo quarry; b. Valinho do Rei quarry; c. Reguengo do Fetal quarry; d. Cabeço do Roxo quarry; e. Outreiro do Sebastião quarry; f. Batalha Monastery, Royal Cloister; g. Batalha Monastery roof top; h. Batalha Monastery eaves arch; i. Batalha Monastery church railing 1; j. Batalha Monastery church railing 2; k. Batalha Monastery church baluster. 
Table 1. Petrographic features of limestone thin sections.

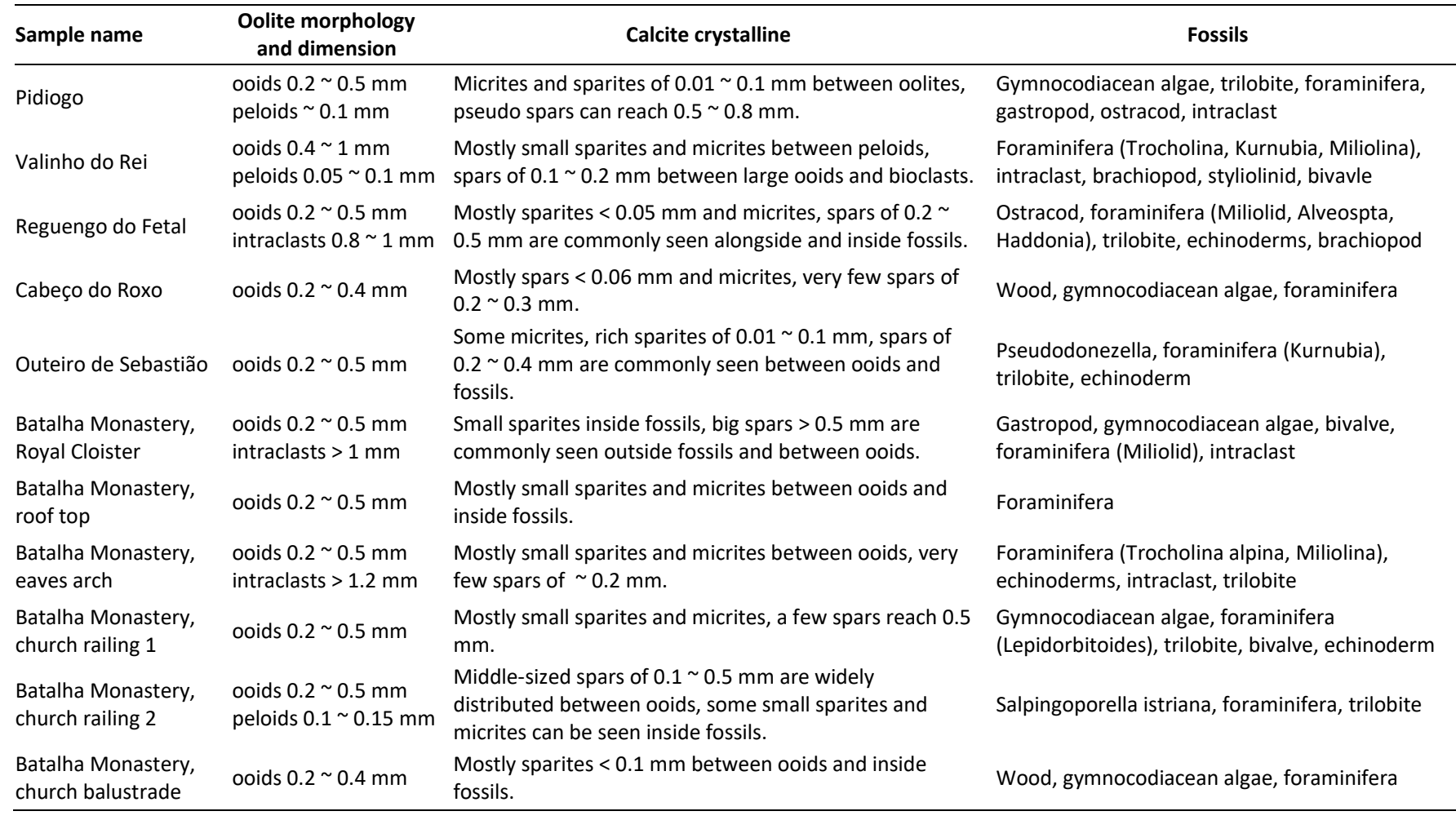

(1 $\mathrm{mm})$. The Outreiro de Sebastião quarry, the Batalha Monastery royal cloister and church railing 1 contain abundant marine microfossils. Large-sized sparite crystals (up to $0.5 \sim$ $1 \mathrm{~mm}$ ) can be identified as cement between oolites, alongside or inside the fossils, some of which was recrystallised from mud micrites (Figure 4c). According to the Dunham classification, all these stones can be classified as grain supported [19]. The presence of sparry calcitic cements implies the deposition occurred in a high energy environment.

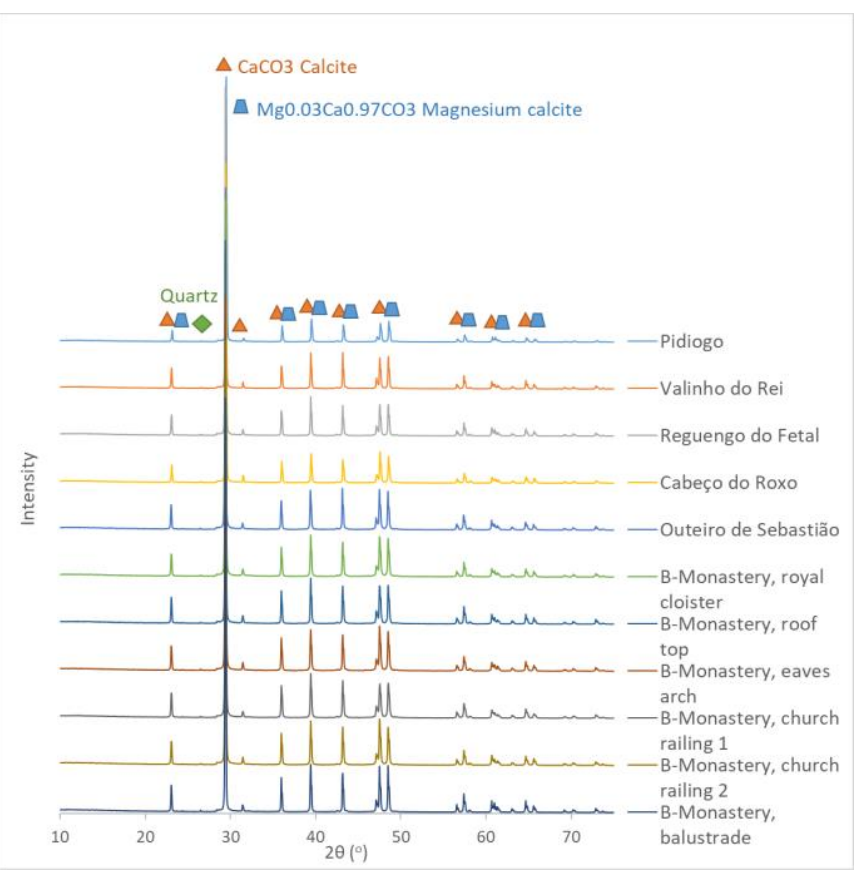

Figure 5. XRD results of the stone samples.
Foraminifera in the samples belonged mostly to four genera: Miliolid, Kurnubia, Trocolina and Haddonia. These foraminifera are found in inner shallow-water platforms from the late Jurassic and early and middle Eocene, indicating the sedimentary environment and the age of these limestones [14]. This deduction matches that of the 'Carta Geológica de Portugal' [20], with the Pidiogo, Valinho do Rei and Reguengo do Fetal quarries showing limestone of Bathonian age and Cabeço do Roxo and Outreiro de Sebastião of Callovian age, both of which are in the middlelate Jurassic period.

The features in Table 2 and described in the above paragraph were summarised from the thin-section photos, which can be found as supplementary data to this article.

\subsection{X-ray diffraction}

Figure 5 shows the XRD scan of all the stone powders from the quarry and monastery samples. The results indicate that all the samples have the same mineral composition: calcite $\left(\mathrm{CaCO}_{3}\right)$, magnesium calcite $\left(\left(\mathrm{Mg}_{0.03} \mathrm{Ca}_{0.97}\right) \mathrm{CO}_{3}\right)$ and quartz $\left(\mathrm{SiO}_{2}\right)$. Semiquantitative analysis provided the content of each mineral; the content of calcite in these limestones is over $95 \%\left(\mathrm{CaCO}_{3} 60 \sim\right.$ $70 \%$ and $\mathrm{Mg}_{0.03} \mathrm{Ca}_{0.97} \mathrm{CO}_{3} 25 \sim 35 \%$ ), while the content of quartz is around or lower than $1 \%$.

For the small peaks, the minerals indicated are whewellite $\left(\mathrm{CaC}_{2} \mathrm{O}_{4} \bullet \mathrm{H}_{2} \mathrm{O}\right)$, sodium phosphate $\left(\mathrm{NaPO}_{3}\right)$, nitratine $\left(\mathrm{NaNO}_{3}\right)$ and pyrophosphite $\left(\mathrm{K}_{2} \mathrm{CaP}_{2} \mathrm{O}_{7}\right)$. However, due to the weak intensity of these peaks (less than $0.5 \%$ ) and the possible overlapping of the major mineral peaks, this identification is inconclusive.

\subsection{Thermogravimetric analysis}

Figure 6 shows the weight loss of one sample according to temperature increase. A mass loss in the temperature range of $600{ }^{\circ} \mathrm{C}-800{ }^{\circ} \mathrm{C}$ was observed, indicating the decomposition reaction of calcite [21]: $\mathrm{CaCO}_{3} \rightarrow \mathrm{CaO}+\mathrm{CO}_{2}$. The differential 


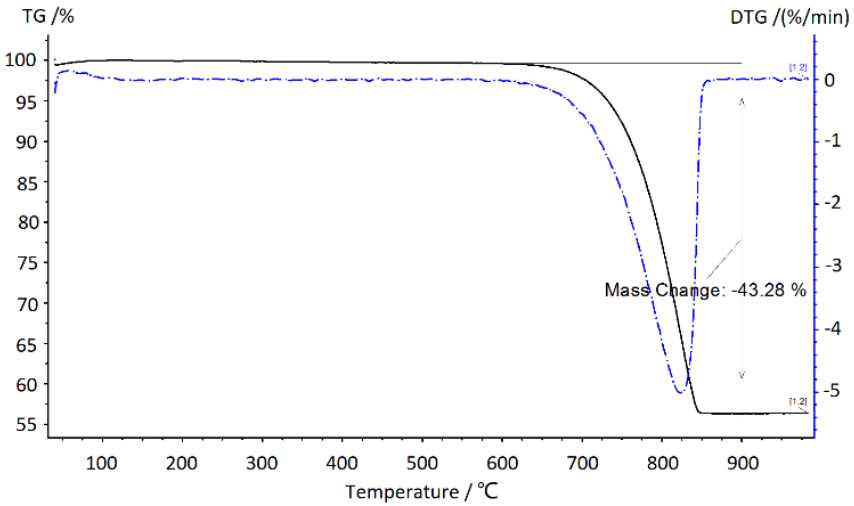

Figure 6. TGA curve of stone from the Batalha Monastery baluster.

of the thermal gravity curve showed the reaction to be single stepped. There is no mass change in other temperature ranges, demonstrating no absorbed water, gypsum, portlandite or muscovite in these stones. As seen in Table 2, the calculated results show that the proportion of calcite in all the samples reaches $97.2 \mathrm{wt}^{\%} \% \sim 99.2 \mathrm{wt} \%$. It should be noted that the molar mass of $\mathrm{CaCO}_{3}$ was used in the calculation, thus the actual proportion of calcite would be lower than this number; this minor inaccuracy comes from the $\mathrm{Mg}$ in magnesium calcite.

Slight differences could be seen by comparing the curves of all the samples. For example, limestone from the Valinho do Rei quarry showed obvious weight change after the temperature reached $600{ }^{\circ} \mathrm{C}$, while for the sample from Outreiro de Sebastião, it was after $630^{\circ} \mathrm{C}$. A feasible thermodynamic explanation for this phenomenon is that a larger particle size causes the activation energy to be higher, thus consuming more energy to initiate the decomposition process [22]. Grain size can also affect the reaction speed; limestone, with a small grain size, has a higher thermal decomposition rate [23]. This is in accordance with thinsection observation, as the major component of the Valinho do Rei limestone is characterised by micritic cement between small peloids, while the Outreiro de Sebastião limestone has larger ooids, more fossils and larger recrystallised sparite cements.

\subsection{X-ray fluorescence analysis}

Figure 7 illustrates the relative intensity of each element in the limestone samples. Besides calcium, other elements detected in the limestone were silicon, phosphorous, sulphur, strontium, yttrium, zirconium, niobium, barium, thorium, lead, uranium and chlorine. The overall ratio of these elements is rather homogeneously distributed, with the exception of the Batalha

Table 2. Calcite proportion from TGA calculation

\begin{tabular}{lcc}
\hline Sample & $\begin{array}{c}\text { Weight loss } \\
\text { (wt\%) }\end{array}$ & Calcite (wt\%) \\
\hline Pidiogo & 43.93 & 99.9 \\
Valinho do Rei & 43.58 & 99.1 \\
Reguengo do Fetal & 43.85 & 99.7 \\
Cabeço do Roxo & 43.24 & 98.3 \\
Outeiro de Sebastião & 43.23 & 98.3 \\
Batalha Monastery, Royal Cloister & 42.77 & 97.2 \\
Batalha Monastery roof top & 43.48 & 98.9 \\
Batalha Monastery eaves arch & 43.39 & 98.6 \\
Batalha Monastery church railing 1 & 43.21 & 98.2 \\
Batalha Monastery church railing 2 & 43.64 & 99.2 \\
Batalha Monastery church baluster & 43.28 & 98.4 \\
\hline
\end{tabular}

Monastery baluster sample, which shows an apparent higher intensity of $\mathrm{P}, \mathrm{S}$ and $\mathrm{Cl}$, and the naturally weathered Valinho do Rei stone, with the highest counts of $\mathrm{Cl}$. This could be explained by the effect of salt weathering [4]. In addition, there is a noticeable disparity in the strontium peak intensity between some samples.

With the same coordination number and similar ion radius, $\mathrm{Sr}^{2+}$ may substitute $\mathrm{Ca}^{2+}$ ions in the calcite crystals. Stones formed in the same geological environment would have similar degrees of such a substitution [24], [25]. From the Ca-Sr element alignment scatter plot (Figure), it can be seen that the plots that represent the Batalha Monastery baluster, Valinho do Rey and Reguengo do Fetal are similar, suggesting a similar slope of $\mathrm{Ca}$ Sr concentration of around $6.0 \times 10^{3}$. However, limestones from the Batalha Monastery Royal Cloister, eaves arch and church railing 2 have similar $\mathrm{Ca}-\mathrm{Sr}$ ratios to the Pidiogo and Cabeço do Roxo quarries of around $3.7 \times 10^{3}$. The plots for the Batalha Monastery roof top $\left(\mathrm{Ca} / \mathrm{Sr}\right.$ ratio $\left.2.8 \times 10^{3}\right)$ and church railing 1 $\left(\mathrm{Ca} /\right.$ Sr ratio $\left.2.3 \times 10^{3}\right)$ are not similar to any existing quarry samples; a possible explanation is that these stones were from the lost Carvalhos quarry.

\section{CONCLUSIONS}

A combined multi-analytical approach was used to establish the quarries of provenance for the Batalha Monastery. Since considerable historical evidence can be drawn from the study of material provenance, these techniques have provided a powerful tool for the collection and analysis of valuable information of special interest to conservation research. The petrographic study confirmed that stones from the Batalha Monastery and the quarries that were used for construction and restoration are all oolitic limestones, dating back to the middle-late Jurassic period and deposited on inner shallow-water platforms at the edge of the continental shelf. XRD and TGA showed a high content of calcite $(>97 \mathrm{wt} \%)$ and a small amount of quartz $(\leq 1 \mathrm{wt} \%)$. Furthermore, to correlate each quarry with the different parts of the monastery, a Ca-Sr correlation chart was developed based on the ED-XRF result, suggesting that the monastery baluster was made of stone from the Valinho do Rei or Reguengo do Fetal quarries, while part of the church railing, the north-aisle eaves arch and Royal Cloister were constructed from stones from the Pidiogo or Cabeço do Roxo quarries. These analytical results confirm the quarry-source attribution for the Batalha building

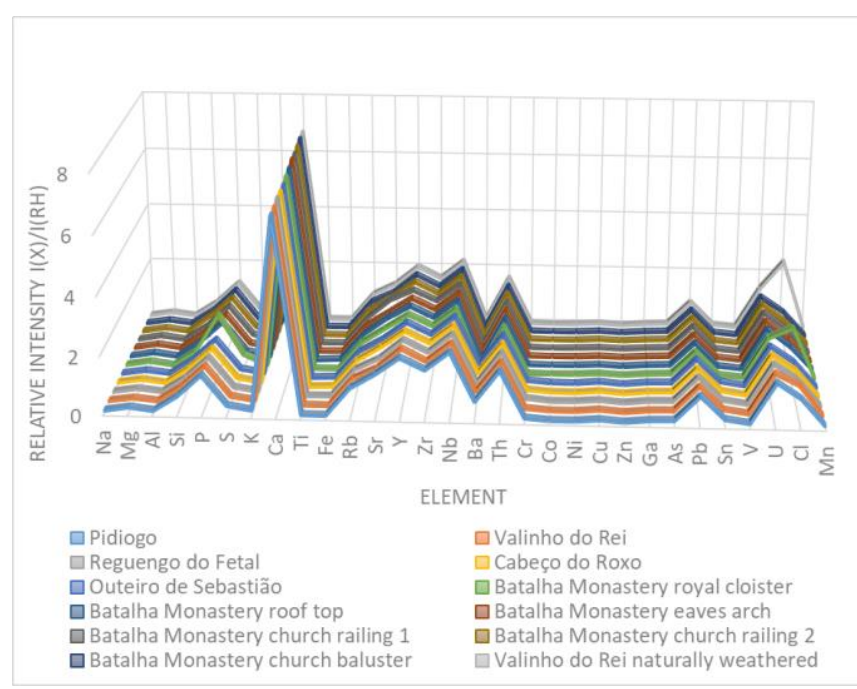

Figure 7. XRF elemental results. 


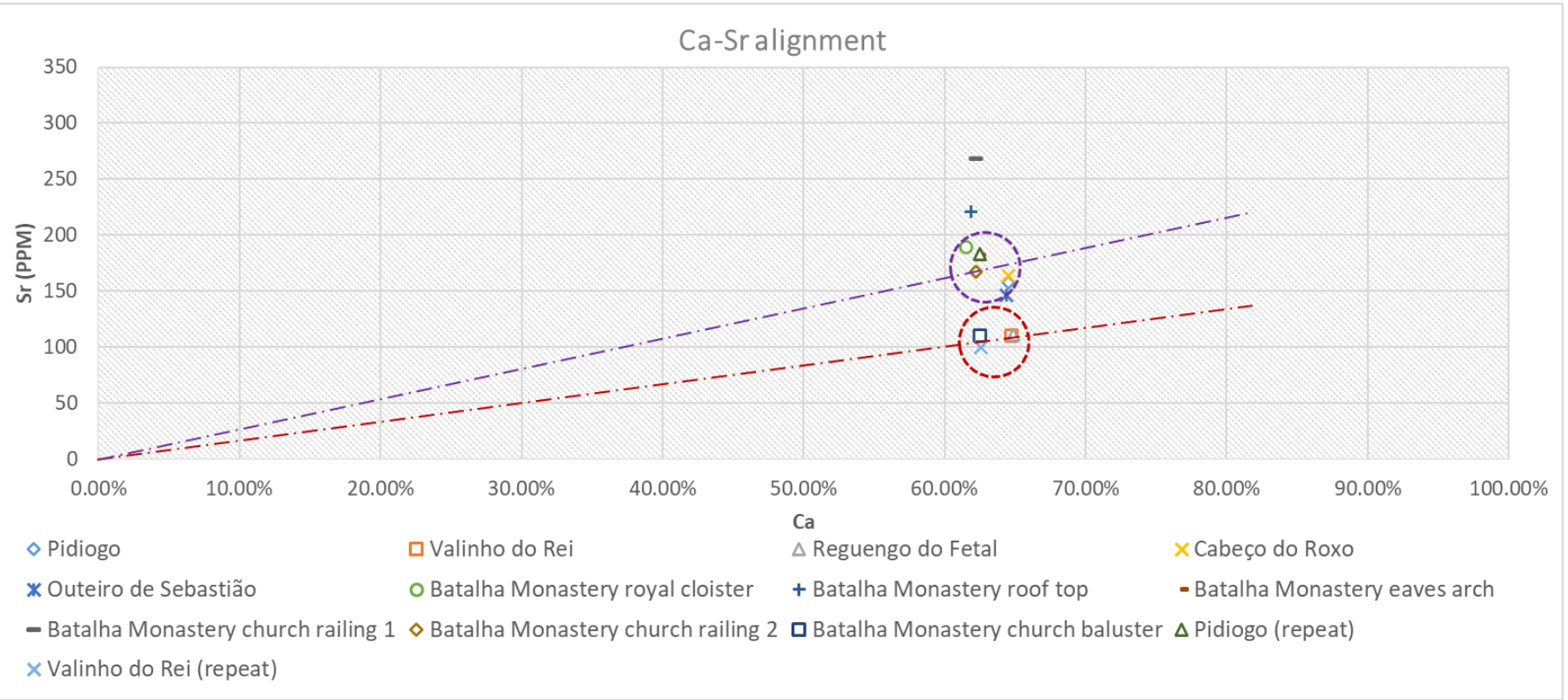

Figure 8. Ca-Sr element alignment based on XRF data.

materials found in the historical documents of the Batalha Monastery. For possible conservation and restoration in the future, this research can provide a reference for the selection of stones in order to obtain equivalent physicochemical and mechanical properties to maintain the consistency and integrity of the historical monument.

To complement the current study, inductively coupled plasma-mass spectroscopy (ICP-MS) analyses will be conducted to obtain minor and trace element data on samples from both the monastery and the quarries identified in this study to further confirm the results [26]. In future restoration interventions, finite element analysis could also be used to investigate the mechanical behaviour, which can take into account the different states of preservation of the original materials and those used during restoration [27], [28].

\section{ACKNOWLEDGEMENT}

The research presented in this paper was carried out mainly using data collected at Universidade de Évora, Politecnico di Torino and Direcao-Geral do Patrimonio Cultural, as part of H2020-MSCA-ITN-2017, ED-ARCHMAT (ESR1). This project has received funding from the European Union's Horizon 2020 research and innovation programme under the Marie Skłodowska-Curie grant agreement no. 766311.

\section{REFERENCES}

[1] J. C. V. Da Silva, The Monastery of Batalha, Scala Books, London, 2007, ISBN 978-1857593822.

[2] B. T. Gemeda, R. Lahoz, A. T. Caldeira, N. Schiavon, Efficacy of laser cleaning in the removal of biological patina on the volcanic scoria of the rock-hewn churches of Lalibela, Ethiopia, Environmental Earth Sciences 77 (2018), p. 36. DOI: $10.1007 / \mathrm{s} 12665-017-7223-3$

[3] N. Schiavon, A. Candeias, T. Ferreira, M. Da Conceiçao Lopes, A. Carneiro, T. Calligaro, J. Mirao, A combined multi-analytical approach for the study of Roman glass from south-west Iberia: synchrotron $\mu$-XRF, external-PIXE/PIGE and BSEMEDS, Archaeometry 54 (2012), pp. 974-996. DOI: $\underline{10.1111 / \mathrm{j} .1475-4754.2012 .00662 . \mathrm{x}}$
[4] S. Siegesmund, R. Snethlage, Stone in Architecture: Properties, Durability, Springer Science \& Business Media, Berlin, 2011, ISBN 978-3-642-45155-3.

[5] M. Sammarco, S. Margiotta, L. M. Foresi, G. Ceraudo, Characterization and provenance of building materials from the Roman Pier at San Cataldo (Lecce, Southern Apulia, Italy): a lithostratigraphical and micropaleonthological approach, Mediterranean Archaeology and Archaeometry 15 (2015), pp. 101-112.

DOI: http://doi.org/10.5281/zenodo.16604

[6] L. Bianco, Techniques to determine the provenance of limestone used in Neolithic Architecture of Malta, Romanian Journal of Physics 62 (2017). 901. Online [Accessed 26 March 2021] https://www.um.edu.mt/library/oar/bitstream/123456789/205 08/1/rip062 1-2 901.pdf

[7] M. Brilli, F. Antonelli, F. Giustini, L. Lazzarini, P. Pensabene, Black limestones used in antiquity: the petrographic, isotopic and EPR database for provenance determination, Journal of Archaeological Science 37 (2010), pp. 994-1005.

DOI: $10.1016 /$ i.jas.2009.11.032

[8] L. Aires-Barros, As Rochas dos Monumentos Portugueses: Tipologias e Patologias, Volume II, Instituto Português do Património Arquitectónico, Lisbon, 2001, ISBN 9789728087814.

[9] Edital n. ${ }^{\circ}$ 03/2017/g.A.P. Sítio de interesse municipal da pedreira histórica de Valinho do Rei e sítio de interesse municipal da pedreira histórica de Pidiogo - criação de zona especial de proteção (zep).

[10] C. M. Soares, O Restauro do Mosteiro da Batalha: Pedreiras Históricas, Estaleiro de Obras e Mestres Canteiros, Magno Ed., Leiria, 2001. ISBN 9789728345280.

[11] C. R. Hubbard, E. H. Evans, D. K. Smith, The reference intensity ratio, I/Ic, for computer simulated powder patterns, Journal of Applied Crystallography 9 (1976), pp. 169-174. DOI: $10.1107 /$ S0021889876010807

[12] J. Lasne, A. Noblet, C. Szopa, R. Navarro-González, M. Cabane, O. Poch, F. Stalport, P. François, S. K. Atreya, and P. Coll, Oxidants at the surface of Mars: a review in light of recent exploration results, Astrobiology 16 (2016), pp. 977-996. DOI: $10.1089 /$ ast. 2016.1502

[13] M. Beltrame, M. Liberato, J. Mirão, H. Santos, P. Barrulas, F. Branco, Gonçalves, L., A. Candeias, Schiavon, N, Islamic and post Islamic ceramics from the town of Santarem (Portugal): the continuity of ceramic technology in a transforming society, Journal of Archaeological Science: Reports 23 (2019), pp. 
910-928.

DOI: $10.1016 /$ j.jasrep.2018.11.029

[14] E. Flügel, Fossils in thin section: it is not that difficult, in: Microfacies of Carbonate Rocks. E. Flügel (editor). Springer, Berlin, Heidelberg, 2004, ISBN 978-3-662-08726-8, pp. 399-574. DOI: $10.1007 / 978-3-642-03796-2 \quad 10$

[15] E. Flügel, Microfacies of Carbonate Rocks: Analysis, Interpretation and Application, Springer Science \& Business Media, Berlin, 2013, ISBN 978-3-662-08726-8.

[16] E. Flügel, Microfacies data: matrix and grains, in: Microfacies of Carbonate Rocks. E. Flügel (editor). Springer, Berlin, Heidelberg, 2004, ISBN 978-3-662-08726-8, pp. 73-176

[17] C. Solak, K. Taslı, H. Koç, Biostratigraphy and facies analysis of the Upper Cretaceous-Danian platform carbonate succession in the Kuyucak area, western Central Taurides, S Turkey, Cretaceous Research 79 (2017), pp. 43-63. DOI: $10.1016 /$ j.cretres.2017.06.019

[18] D. Ivanova, B. Kołodziej, E. Koleva-Rekalova, E. Roniewicz, Oxfordian to Valanginian palaeoenvironmental evolution on the western Moesian Carbonate Platform: a case study from SW Bulgaria, Annales Societatis Geologorum Poloniae 78 (2008), pp. 65-90.

[19] S. W. Lokier, M. Al Junaibi, The petrographic description of carbonate facies: are we all speaking the same language?, Sedimentology 63 (2016), pp. 1843-1885.

DOI: $\underline{10.1111 / \text { sed.12293 }}$

[20] Carta Geologica de Portugal, 1:50,000, Sheet 27-A Vila Nova de Ourém, Instituto Geológico e Mineiro, Departamento de Geologia, Lisbon, 1998.

[21] F. de Souza, S. R. Bragança, Thermogravimetric analysis of limestones with different contents of $\mathrm{MgO}$ and microstructural characterization in oxy-combustion, Thermochimica Acta 561 (2013), pp. 19-25. DOI: $10.1016 /$ i.tca.2013.03.006

[22] M. Mohamed, S. Yusup, S. Maitra, Decomposition study of calcium carbonate in cockle shell, Journal of Engineering Science and Technology 7 (2012), pp. 1-10.
[23] D. Xu, H. Wei, Y. Luo, The influence of grain size on decomposition reaction of limestone in dispersing state, Journal of Wuhan Univ. of Technology-Mater. Sci. Ed. 19 (2004), pp. 1-5. DOI: $10.1007 / \mathrm{BF} 02841354$

[24] L. Lazzarini, G. Moschini, B. M. Stievano, A contribution to the identification of Italian, Greek and Anatolian marbles through a petrological study and the evaluation of calcium/strontium ratio, Archaeometry 22 (1980), pp. 173-183.

[25] Y. Yamashita, T. Otake, H. Yamada, Relative contributions from exposed inshore and estuarine nursery grounds to the recruitment of stone flounder, Platichthys bicoloratus, estimated using otolith Sr: Ca ratios, Fisheries Oceanography 9 (2000), pp. 316-327. DOI: $\underline{10.1046 / j .1365-2419.2000 .00147 . x}$

[26] E. K. Bartle, R. J. Watling, Provenance determination of oriental porcelain using laser ablation-inductively coupled plasma-mass spectrometry (LA-ICP-MS), Journal of Forensic Sciences 52 (2007), pp. 341-348.

DOI: $10.1111 / \mathrm{j} .1556-4029.2006 .00364 . \mathrm{x}$

[27] Z. Vangelatos, M. Delagrammatikas, O. Papadopoulou, P. Vassiliou, Computational modelling of the mechanical behaviour of the Pentelic marble-steel clamp system on the structures of the Athens Acropolis, Proc. of the 2019 IMEKO TC4 International Conference on Metrology for Archaeology and Cultural Heritage Florence, Italy, 4-6 December 2019, pp. 516-521, Online [Accessed 26 March 2021] https://www.imeko.org/publications/tc4-Archaeo2019/IMEKO-TC4-METROARCHAEO-2019-101.pdf

[28] M. Kyritsis-Spinoulas, Z. Vangelatos, P. Vassiliou, D. Manolakos, M. Delagrammatikas, O. Papadopoulou, Steel clamps from the Acropolis: some old, some new and some digital, Proc. of the 5th International Conference on Corrosion Mitigation and Surface Protection Technologies, Luxor, Egypt, 11-18 December 2016, pp. 11-18. 